\title{
Preface-evaluating the response of critical zone processes to human impacts with sediment source fingerprinting
}

\author{
J. Patrick Laceby ${ }^{1}$ (D) $\cdot$ Allen C. Gellis ${ }^{2} \cdot$ Alexander J. Koiter $^{3} \cdot$ Will H. Blake ${ }^{4} \cdot$ Olivier Evrard $^{5}$
}

Received: 15 July 2019 / Accepted: 15 July 2019 / Published online: 31 July 2019

(C) Springer-Verlag GmbH Germany, part of Springer Nature 2019

\section{Background: critical zone processes in the Anthropocene}

The Earth's critical zone encompasses a suite of interconnected processes in the near-surface lithosphere, pedosphere, biosphere, atmosphere, and hydrosphere (Brantley et al. 2007; Lin 2010) (Fig. 1). Processes and interactions both within and between these various critical zone components support life-sustaining ecosystem services and resources that establish the foundation for humanity (NRC 2001). This includes the production of fertile soils; flourishing vegetation; productive rivers, lakes, and oceans; and our life-sustaining atmosphere (Gaillardet 2014; Guo and Lin 2016).

Rapid population growth, land-use intensification, and global environmental change are disturbing many of these fundamental critical zone processes. More than half of the Earth's terrestrial surface is now impacted by anthropogenic activities (e.g., clearing, grazing, plowing, mining, and logging) (Richter and Mobley 2009; Hooke et al. 2012). These changes are so widespread and pervasive that the great acceleration of socioeconomic development that occurred around

J. Patrick Laceby

patrick.laceby@gov.ab.ca

1 Environmental Monitoring and Science Division, Alberta Environment and Parks, 3535 Research Rd NW, Calgary, Alberta, Canada

2 U.S. Geological Survey, 5522 Research Park Drive, Baltimore, MD 21228, USA

3 Department of Geography and Environment, Brandon University, 270 18th St, Brandon, MB R7A 6A9, Canada

4 School of Geography, Earth and Environmental Sciences, University of Plymouth, Plymouth PL4 8AA, UK

5 Laboratoire des Sciences du Climat et de l'Environnement, LSCE/IPSL, UMR 8212 (CEA-CNRS-UVSQ), Université Paris-Saclay, 91191 Gif-sur-Yvette Cedex, France
1950 (Fig. 2) has been identified as the dawn of the Anthropocene (Waters et al. 2016). Although the utility of adopting and delineating the Anthropocene as the current epoch is subject to debate (Crutzen 2002; Smith and Zeder 2013; Ruddiman et al. 2015), the concept effectively highlights both the nature and the extent of our global impact on Earth's critical zone.

Soil-forming processes and ecosystem services provided by the pedosphere are central to the critical zone (Lin 2010; Banwart et al. 2011). Many of these processes have been disturbed by the agricultural intensification that coincided with the great acceleration resulting in unsustainable landuse practices now outpacing soil formation processes (Brantley et al. 2007). As agricultural landscapes now cover an area equivalent to what was scoured during the last glacial maximum (Amundson et al. 2007), the broad-scale intensification of anthropogenic activities has resulted in significant on- and off-site impacts. On-site, soil loss has resulted in decreases in soil fertility and agricultural yields (Ladha et al. 2009) threatening the ability to feed the world's growing population (Brantley et al. 2007). Off-site, the excess delivery of particulate matter downstream is degrading riverine, lacustrine, and estuarine ecosystems (Clark 1985; Owens et al. 2005; Bilotta and Brazier 2008; Smith et al. 2018).

The challenge, as noted by Brantley et al. (2007), is that despite our society having over 10,000 years of experience working with soils, our conceptual and quantitative models remain inadequate at predicting critical zone dynamics under current conditions. Notwithstanding growing pressure for improved environmental management, we still have a limited capacity to predict changes in the critical zone in response to anthropogenic activities owing to the multiple spatial and temporal scales at which these complex processes and feedbacks are manifested. As river basin systems are impacted by many of these processes, a deeper understanding of the dynamics of the soil-sediment continuum may provide a valuable framework for evaluating the disturbance response of critical zone processes. Understanding these processes may also provide 


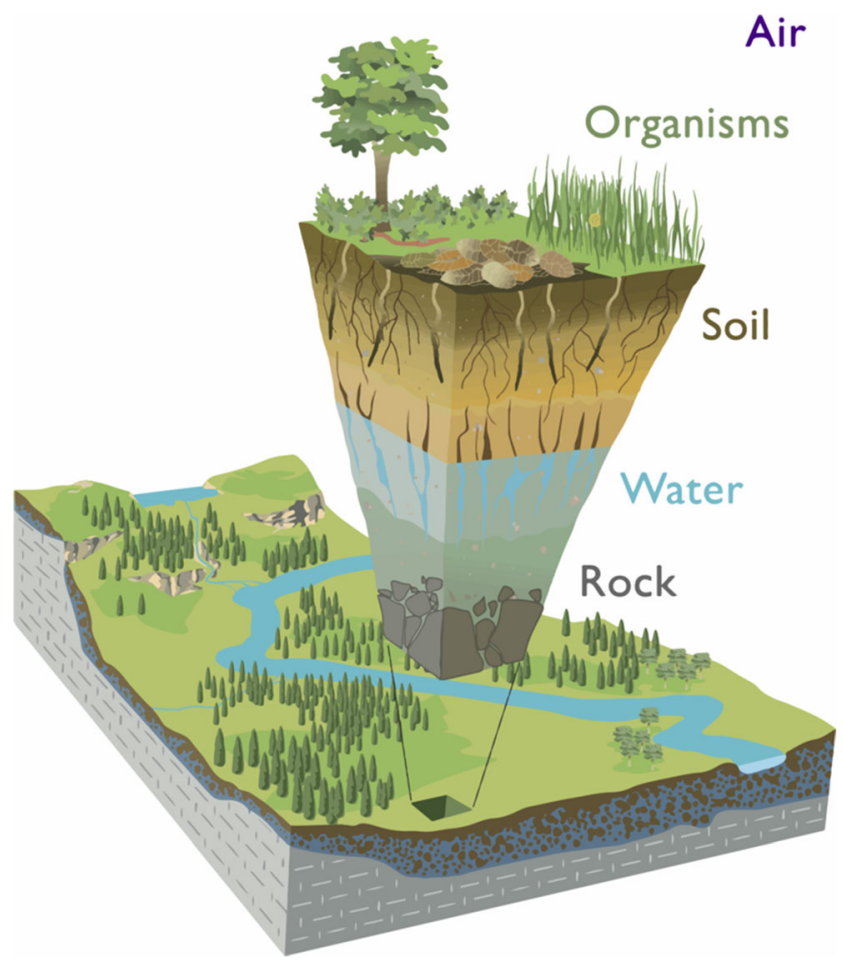

Fig. 1 Conceptual illustration

of the critical zone, courtesy: National Science Foundation (NSF-CZO, 2019)

land and resource managers with the information necessary to manage both the on-site and off-site effects of accelerated soil erosion.

\section{Sediment source fingerprinting}

The sediment source fingerprinting technique is well suited to investigate critical zone processes within river basins. The

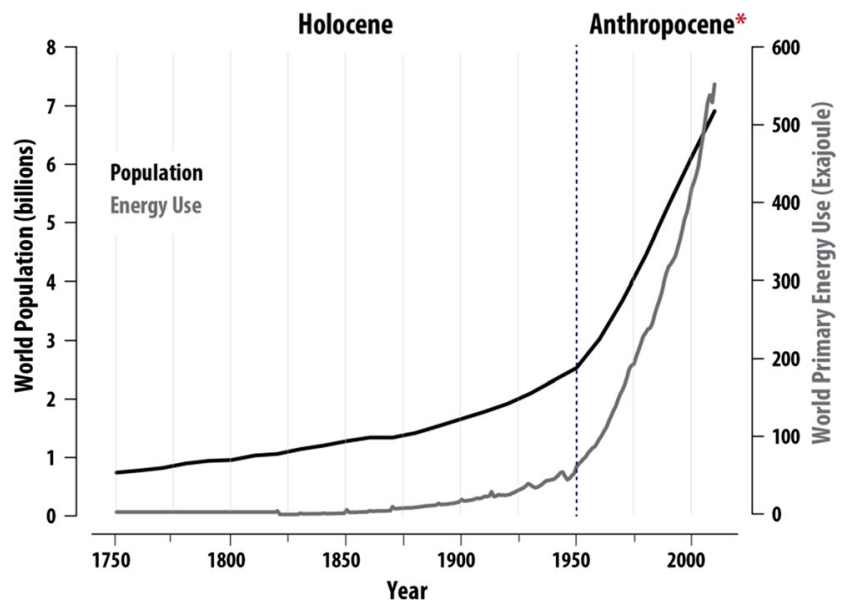

Fig. 2 The dawn of the Anthropocene, delineated by the great acceleration in 1950, which is highlighted in this figure by an exponential increase in the global population and primary energy use (after Steffen et al. 2015) dynamics of material transported from source to sink through river networks reflect physical and biogeochemical processes occurring in the critical zone (Amundson et al. 2007). Accordingly, the sediment fingerprinting technique is uniquely situated to investigate these processes across a range of spatial and temporal scales, from small fields to regional river basins and from individual rainfall events to decadal timeframes.

The sediment source fingerprinting technique uses a variety of physical and biogeochemical parameters, or fingerprints, to trace sediments back to their sources (Fig. 3). For parameters to be effective fingerprints, they need to discriminate between sediment sources while behaving conservatively (Walling et al. 1993; Collins et al. 1996). Conservative fingerprints remain constant during the erosion cycle (sediment detachment, entrainment, transportation, deposition, and delivery), or vary in a predictable way (Davis and Fox 2009; Koiter et al. 2013b; Belmont et al. 2014; Laceby et al. 2017). A variety of fingerprints have been used to investigate sediment dynamics within river basins, such as mineral magnetic properties, fallout radionuclides, color properties, major and trace element geochemistry, carbon and nitrogen isotopes, and compound-specific stable isotopes (Walling and Kane 1984; Caitcheon 1993; Murray et al. 1993; Martínez-Carreras et al. 2010; Evrard et al. 2011; Blake et al. 2012; Hancock and Revill 2013; Laceby et al. 2016). Fingerprints that discriminate between the sources of interest (e.g., land use, soil types, geology, surface versus subsoils) are used to estimate relative source contributions to target sediment with end-member mixing models that are generally solved stochastically in frequentist (Walling et al. 1993; Collins et al. 2012; Tiecher et al. 2019) or Bayesian frameworks (Small

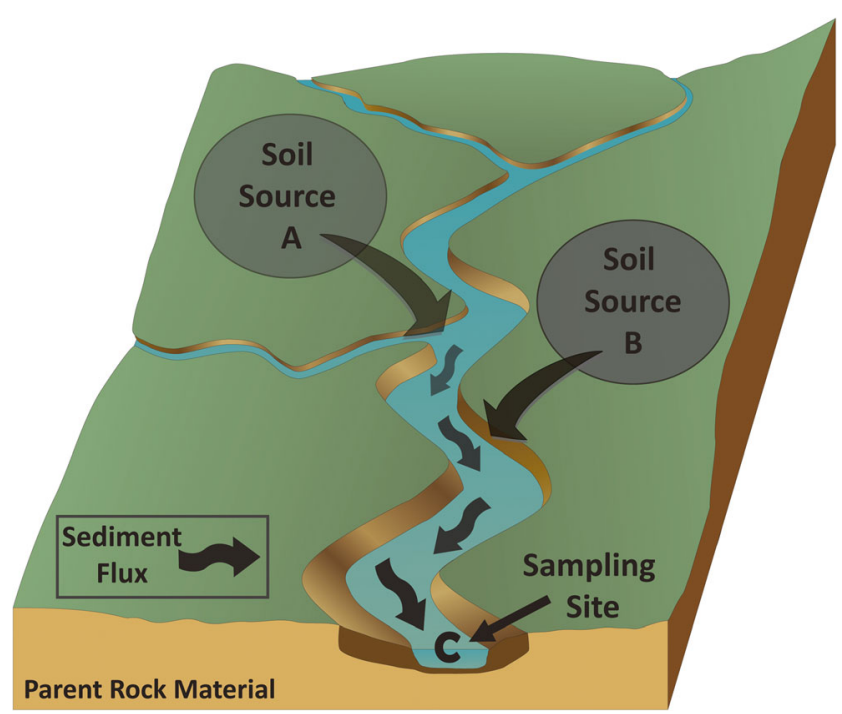

Fig. 3 A simplified two source conceptual model of the sediment source fingerprinting technique where end-member mixing models solve equations (i.e., $\mathrm{Ax}+\mathrm{B}(1-\mathrm{x})=\mathrm{C}$ ) to determine the relative contributions $(\mathrm{x})$ of source A and source B to the target sediment (i.e., $\mathrm{C}$ in the equation) obtained from the sampling site 
et al. 2002; Cooper and Krueger 2017; Davies et al. 2018). The sources discriminated in sediment fingerprinting are typically related to the scale of the study catchment, the complexity of land use, land cover, soil types, and geology, along with the fundamental objectives of the research and/or management program.

Sediment source fingerprinting research originally had a strong focus on understanding erosion dynamics (Wood 1978; Oldfield et al. 1979; Longmore et al. 1983; Stott, 1986; Wallbrink and Murray 1993; Wallbrink et al. 1998). Thereafter, this research started to increasingly focus on identifying sediment sources in the context of developing effective sediment management strategies (Wallbrink 2004; Walling 2005; Davis and Fox 2009; Porto et al. 2010; Gellis and Walling 2011; Mukundan et al. 2012). This emphasis on developing a sediment fingerprinting management tool coincided with a significant research focus on advancing end-member mixing modeling techniques and reducing mixing model uncertainty (Collins et al. 2012; Cooper et al. 2015; Laceby and Olley 2015; Pulley et al. 2015; Sherriff et al. 2015).

Over the last several decades, there has been significant progress in the application and development of the sediment source fingerprinting technique to contribute to the improved management of water bodies around the world. There have been multiple comprehensive review papers on fingerprinting techniques (Collins and Walling 2002; Davis and Fox 2009; D’Haen et al. 2012; Guzmán et al. 2013; Haddadchi et al. 2013; Koiter et al. 2013b; Smith et al. 2013; Owens et al. 2016; Davies et al. 2018) and several special issues dedicated to advancing the sediment source fingerprinting technique and facilitating targeted sediment management strategies (Gellis and Mukundan 2013; Walling et al. 2013; Smith et al. 2015; Collins et al. 2017). Although the sediment source fingerprinting technique has advanced significantly, it has simultaneously drifted away from one of its original foci, researching fundamental Earth system science processes.

Error analysis and uncertainty associated with sediment source fingerprinting has also significantly improved using methods such as Monte Carlo substitutions (Kraushaar et al. 2015; Gellis and Gorman Sanisaca 2018; Collins et al. 2019), virtual mixtures (Laceby and Olley 2015; Palazón et al. 2015; Collins et al. 2019), synthetic mixtures (Sherriff et al. 2015), and Bayesian uncertainty estimations (i.e., Markov chain Monte Carlo framework) (Small et al. 2002; Stewart et al. 2015).

Limitations still exist within the sediment source fingerprinting framework including spatial and temporal challenges that may affect the interpretation of individual studies. Temporal limitations include the time period of source assessment where longer time periods may be required to characterize seasonal sources (i.e., during cultivation), the general hydrology of the study area, and sample large storm events. The main challenge is that longer study periods involve significant additional costs. Sediment sources may also change over the storm hydrograph and integration of sediment for an entire storm based on individual samples may not reflect the true source contributions (Carter et al. 2003; Nosrati et al. 2018). Separating target samples into rising and falling stages may allow for the interpretation of sediment sources over the hydrograph (Carter et al. 2003; Belmont et al. 2014) but require proper instrumentation and collection of enough sediment mass for analysis. Spatial limitations in sediment source fingerprinting include the catchment area, whereas size increases the number of samples collected to characterize sources, along with additional costs (Nosrati and Collins 2019). Parts of the watershed that are difficult to access because of landowner permission, or are remote, may also present a challenge for acquiring representative datasets (Nosrati and Collins 2019). Finally, while sediment fingerprinting quantifies the general sources of delivered sediment to the point of interest, it does not highlight specific locations or "hot spots" of erosion within a watershed, which often need to be identified with sediment budgets or other approaches (Gellis and Walling 2011).

\section{Sediment source fingerprinting in the critical zone}

This special issue presents a series of research articles demonstrating how sediment source fingerprinting research can be used to investigate a variety of critical zone processes. Understanding critical zone processes and their response to human impact is imperative for adapting to global change and meeting United Nations' sustainable development goals (Griggs et al. 2013). Therefore, we hope to demonstrate how the sediment source fingerprinting technique offers potential to further our understanding of critical zone processes in river basin systems around the world. Accordingly, in this section, we highlight the key contributions from the research papers in this special issue from multiple researchers applying the sediment source fingerprinting technique in Asia, Europe, North America, and South America.

Uber et al. (2019) investigate the spatial origin of suspended sediment in two nested catchments (i.e., Claduègne and Gazel Basins, France) from a French critical zone observatory network: the Cevennes-Vivarais Mediterranean Hydrometeorological Observatory. Critical zone observatories are important collaborative platforms for research that often operate at the watershed scale and focus on the interconnected chemical, physical, and biological processes shaping Earth's surface. At this particular hydro-meteorological observatory, these authors incorporate multiple suites of fingerprints (i.e., color, X-ray fluorescence, and magnetic susceptibility) to investigate whether sediment is derived from erosion processes on badlands, sedimentary topsoils, or basaltic topsoils. Uber et al. (2019) 
found that erosion processes on the badlands contributed between 74 and $84 \%$ of the suspended sediment, followed by erosion processes on sedimentary (12-29\%) and basaltic (1$8 \%$ ) surface soils. Importantly, these authors demonstrated that the choice of the fingerprints included in the mixing model had a larger impact on the model results than the actual model used to apportion sediment sources. One of Uber et al.'s (2019) key findings is the importance of using multi-fingerprint and multimodel techniques to detect and quantify potential biases (e.g., source variability, particle-size selectivity) in order to obtain reliable and robust estimates of source contributions to target sediment.

Batista et al. (2019) examine how pedogenetic processes in soils help influence the development of the geochemical signals that are used in sediment source fingerprinting research. Their research in the Ingaí River Basin (Brazil) incorporated a tributary fingerprinting technique, multiple particle-size fractions, and artificial mixtures to understand erosion dynamics in three areas of this basin: the upper, middle, and lower regions. In particular, Batista et al. (2019) found that erosion processes on Ustorthrent soils from the lower catchment were dominating the supply of sediment at the basin outlet. In particular, these authors reported that using different techniques to select elements for inclusion in mixing models (e.g., knowledge and statistics based), along with artificial mixtures, helped provide multiple lines of evidence necessary to produce robust estimates of source contributions to target sediments. Batista et al. (2019) illustrate the importance of understanding how pedogenetic processes drive source signal (i.e., fingerprint) development. In closing, Batista et al. (2019) argue that the use of knowledge-based techniques to select fingerprints for modeling will encourage researchers to further develop their understanding of processes that drive erosion and sediment geochemistry across multiple spatial and temporal scales.

Evrard et al. (2019a) use colorimetric fingerprints to investigate the contribution of different erosion processes to material transiting the Mano and Niida catchments in the Fukushima Prefecture, Japan. The authors demonstrated that erosion processes on cultivated landscapes supplied the majority of sediment $(56 \%)$ to the river networks followed by subsoil sources (including decontaminated materials-26\%) and forest sources $(21 \%)$. The relative contribution of these sources changed over time owing to the implementation of decontamination activities in the region and also to the occurrence of major rainfall events, including typhoons. Importantly, the authors concluded that the relatively inexpensive, rapid, and non-destructive colorimetric measurements have significant potential to provide comprehensive information on erosion processes occurring in the critical zone.

Boudreault et al. (2019) combine the use of colorimetric fingerprints with fallout radionuclides to compare different sampling designs for sediment source fingerprinting in an agricultural catchment in Atlantic Canada. Specifically, the authors investigated whether suspended sediments were derived from streambanks, agricultural topsoil, or forested areas. Boudreault et al. (2019) used a novel nested approach in their sample design, including five sites with drainage basins ranging from 3.0 to $13.4 \mathrm{~km}^{2}$. These authors determined that sediment sampled in the headwaters was predominantly derived from erosion processes in forested areas. Progressing downstream, the authors illustrated that erosion processes on agricultural landscapes started to dominate the supply of sediment in the Black Brook watershed. Boudreault et al. (2019) reported that sediment was mainly derived from local sources rather than upstream sediment entering an individual subcatchment, highlighting the importance of assessing sediment sources over a range of spatial scales to understand geomorphic connectivity.

Kitch et al. (2019) use elemental geochemistry to investigate the sediment source contributions to both suspended sediment and channel bed sediment in the Merriott Stream catchment in rural Somerset, UK. In particular, the authors investigate how upstream agricultural land-management practices impact overland flow generation and affect downstream fluvial processes. Kitch et al. (2019) found that while cultivated landscapes were the dominant source of suspended sediment, channel bank erosion was the main source of channel bed sediment. The authors attributed differences in the suspended versus channel bed sources to in-channel incision and bank failure. Importantly, Kitch et al. (2019) highlight how there are likely different processes driving the source dynamics for suspended sediment and sediment deposited on the channel bed. These differences provide not only useful comparisons to help understand sediment source and storage dynamics, but they also provide fundamental information for targeted management strategies focusing on upstream processes that may be responsible for deleterious particulate material migrating downstream.

Mahoney et al. (2019) use a sediment fingerprinting technique to investigate the equilibrium sediment exchange processes in the Upper South Elkhorn Basin in the USA. In particular, these authors use carbon stable isotopes $\left(\delta^{13} \mathrm{C}\right)$ to help understand the instantaneous deposition and erosion of suspended sediment on, and from, the streambed. Mahoney et al. (2019) found that streambed sediments were an important source of suspended sediment and dominated the supply of sediment in the fluvial load for low and moderate flow events. In contrast, during high and extreme flow events, upland sources became increasingly important. These authors demonstrated that the equilibrium sediment exchange is a potentially important critical zone process in many riverine systems. Researchers should therefore be cognizant of streambeds that may behave as a potential source. This may be particularly important when using stable isotope signatures or other fingerprints that may potentially undergo biotransformation processes (e.g., diagenesis) when deposited in the riverbed. Furthermore, Mahoney et al. (2019) highlight the importance of coupling sediment source fingerprinting 
techniques with watershed-modeling research to help develop a potentially new class of sediment transport studies with combined fingerprinting/watershed modeling research designs. Importantly, Mahoney et al. (2019) provide six important conclusions for helping develop these new coupled models that will help drive future research programs.

Gateuille et al. (2019) combine fallout radionuclides $\left({ }^{137} \mathrm{Cs}\right.$ and ${ }^{210} \mathrm{~Pb}_{\mathrm{xs}}$ ) with elemental geochemistry to investigate the main sediment sources (i.e., stream bank, agricultural, and forest) in the Nechako River Basin in British Columbia, Canada. Not only did these authors investigate how these erosion sources vary spatially across this catchment, but they also investigated how these sources changed over time based on the analyses of a sediment core from an island on the main stem of the Nechako River. For the main-stem sites, channel bank erosion processes dominated the supply of sediment, particularly downstream of active cut banks or areas where the floodplains are actively eroding. Progressing downstream, there was an increase in sediment derived from erosion processes on agriculture and forested landscapes consistent with the changing land use in the catchment. Gateuille et al. (2019) also found that the construction of a dam in the 1950s resulted in a significant alteration of the sediment transport capacity in the Nechako River Basin, resulting in a change in sediment source dynamics. Overall, Gateuille et al. (2019) demonstrated that the sediment source fingerprinting technique can be utilized to investigate how the cumulative effects of anthropogenic and natural disturbances affect sediment source dynamics in a large river basin over short (i.e., annual) and longer (i.e., decadal) temporal scales.

Gellis et al. (2019) apportion sediment using elemental analysis and the sediment fingerprinting approach and age-date sediment with fallout radionuclides in the agricultural Walnut Creek Basin (Iowa, USA). In particular, the age-dating of sediment provides an important temporal context for understanding sediment source dynamics. In this study, the authors determine that erosion processes on agricultural cropland supply the majority of suspended sediment (62\%) followed by streambank erosion processes $(36 \%)$. Thereafter, the authors applied an age-date model with ${ }^{210} \mathrm{~Pb}_{\mathrm{xs}}$ and ${ }^{7} \mathrm{Be}$ to illustrate that sediments typically reside in three different storage age boxes: a rapid box $(<1$ year), a decadal box (10-100 years), and a geologic box (1001000 years). This research highlights the potential of combining multi-fingerprint suites to simultaneously examine temporal and spatial erosion processes occurring in the critical zone.

Pawlowski and Karwan (2019) examine $\mathrm{Pb}$ and Be sorption dynamics to understand the potential limitations surrounding the use of these fingerprints. The authors use batch experiments with in-stream sediment deposits from two systems and varying solutions to replicate both background and elevated levels of iron oxide along with different dissolved organic carbon and sediment solution ratios. Pawlowski and Karwan (2019) found that the sorption of $\mathrm{Pb}$ and $\mathrm{Be}$ increased over time for all substrates and treatments. These authors demonstrated that sediment mineralogy, organic matter, and biogeochemical cycling processes may all affect the mobilization or retention of $\mathrm{Pb}$ and $\mathrm{Be}$, potentially impacting their conservative behavior and thus their utility in sediment source fingerprinting research. Pawlowski and Karwan (2019) highlight that there may be a significant export of both ${ }^{210} \mathrm{~Pb}_{\mathrm{xs}}$ and ${ }^{7} \mathrm{Be}$ in the solution phase along with other cations that may be exposed to the redox chemistry of a variety of oxides and hydroxides. These authors clearly illustrate how a variety of processes influence the development of fingerprint signals, and that it is important to strive to understand how these processes may affect sediment source fingerprints and source apportionment modeling.

Reiffarth et al. (2019) investigate the potential of compoundspecific stable isotopes (CSSIs) to trace soils derived from different cultivated fields. In particular, the authors examine the spatial variability of carbon isotope ratios $\left(\delta^{13} \mathrm{C}\right)$ from verylong-chain fatty acids at the point, transect, and field scales in an agricultural watershed in Manitoba, Canada. Reiffarth et al. (2019) found that very-long-chain fatty acids do have the potential to trace particulate matter derived from fields cultivated with different cropping species. Although this novel approach to targeting different species or fields could provide significant sediment source information, the authors demonstrate that more research is required into the weighting of subsamples of the source fingerprint, sample design (i.e., targeting flow paths and number of subsamples per field), tracer selection (i.e., which fatty acids to include in mixing models), and intra- and inter-annual tracer isotope variation (i.e., tillage effects and seasonality). The micro-targeting of individual fields with CSSIs and other targeted tracing techniques may help directly identify field and plot scale erosion processes that are disproportionately contributing sediment and sediment-bound contaminants to downstream river networks.

\section{Perspectives for sediment source fingerprinting in the critical zone}

Sediment source fingerprinting research directly or indirectly investigates multiple processes occurring in the critical zone. One sediment source fingerprinting technique uses different fingerprints to determine whether sediments are derived from surface soil erosion (e.g., agricultural topsoil) or subsoil erosion processes (e.g., channel banks, landslides, or gully erosion processes) (Olley et al. 2013; Ben Slimane et al. 2016; Jalowska et al. 2017). A second technique examines how erosion processes on different land uses, soil types, or geologies result in varying source contributions to sediment transiting river systems (Fox 2009; Le Gall et al. 2017; Tiecher et al. 2017). A third technique uses chronological fingerprints to investigate the temporal dynamics of erosion processes, providing 
information on whether sediment may have been eroded in the last year, the last several decades, or even potentially the last hundreds or thousands of years (Taylor et al. 2013; Matisoff 2014; Smith et al. 2014; Evrard et al. 2016). As material being transported through river networks reflect physical and biogeochemical processes occurring in the critical zone (Amundson et al. 2007), the sediment source fingerprinting technique is uniquely situated to investigate and provide further understanding regarding these critical and life-sustaining processes.

To further advance our understanding of the critical zone, we believe it is important for sediment source fingerprinting research to capitalize on combining multiple sediment source fingerprints to explicitly investigate Earth system science processes. In particular, the multi-fingerprint research in this special issue that simultaneously incorporates temporal fingerprints (e.g., ${ }^{7} \mathrm{Be},{ }^{210} \mathrm{~Pb}_{\mathrm{xs}}$ ) with erosion process and spatial fingerprints (Gateuille et al. 2019; Gellis et al. 2019) outlines a potentially effective technique to investigate the response of critical zone processes to anthropogenic activities over multiple temporal scales. For example, short-term fingerprints such as ${ }^{7} \mathrm{Be}$ may provide information on erosion processes occurring on intra-annual temporal scales or even the individual rainfall event scale. Medium-term fingerprints, such as ${ }^{210} \mathrm{~Pb}$ and ${ }^{137} \mathrm{Cs}$ provide erosion process information on decadal time scales (Douglas et al. 2009; Gartner et al. 2012). Longterm fingerprints, such as ${ }^{14} \mathrm{C},{ }^{10} \mathrm{Be}$, and other properties (e.g., optically stimulated luminescence) may provide erosion process information over longer temporal scales (Fig. 4) (Wittmann et al. 2011; Belmont et al. 2014; Bartley et al. 2018).

Coupling temporal tracers with other fingerprints analyzed on sediment cores in riverine, estuarine, or lacustrine environments holds significant potential to provide additional information on processes occurring in the critical zone (e.g., Olley and Caitcheon 2000; Foster et al. 2007; Douglas et al. 2010). The

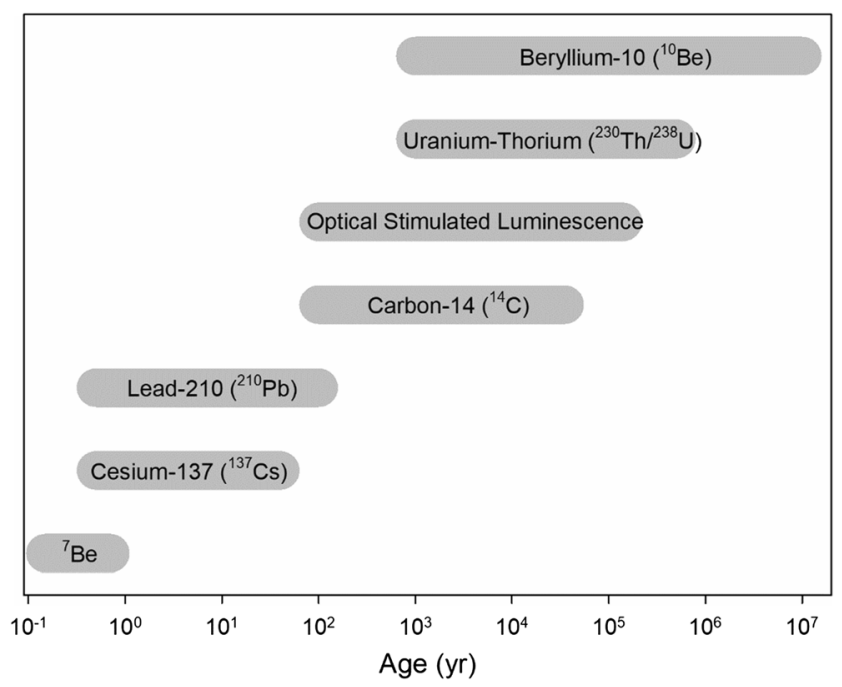

Fig. 4 Approximate dating ranges for a selection of chronological tracers analysis of fingerprints in lacustrine or riverine sediment cores and their comparison to source sample parameters allows for the investigation of particulate matter source dynamics through time; such as changes in geological sources (e.g., increased alluvial/sedimentary source contributions), soil type sources (e.g., Ustorthrent soils), and erosion processes (e.g., increased surface source contributions). Combining temporal tracers and other fingerprints may provide fundamental information on dynamics of multiple processes occurring in the critical zone before and after the great acceleration that has been recommended to mark the dawn of the Anthropocene.

Combining spatial and temporal fingerprints also holds potential to increase our understanding of how the cumulative effects of anthropogenic and natural disturbances affect erosion process dynamics (Gateuille et al. 2019). In particular, it may be possible to investigate how natural disturbances (e.g., a major flooding event) or anthropogenic activities (e.g., agriculture, forestry, and mining) have affected erosion processes over the last century. Coupling sediment source fingerprinting and other watershed sediment modeling research (Mahoney et al. 2019) holds significant potential to improve our understanding of the cumulative effects of multiple disturbances on our increasingly degraded landscapes. Indeed, it will be beneficial to develop fingerprinting research designs that are fully integrated with watershed sediment modeling (Boudreault et al. 2019; Mahoney et al. 2019).

Advances with novel fingerprints such as CSSIs (Blake et al. 2012; Reiffarth et al. 2016) and environmental DNA (Evrard et al. 2019b) may provide direct information regarding changes in cropping or forestry species in a river basin. These next-generation fingerprints may help the sediment source fingerprinting technique move beyond focusing on estimating source contributions to developing a deeper understanding of how multiple processes in the critical zone have been affected by anthropogenic and natural disturbances during the great acceleration.

There are indeed other ways to capitalize on the sediment source fingerprinting framework to understand critical zone processes. For example, Mahoney et al. (2019) utilize the sediment source fingerprinting technique to investigate equilibrium sediment exchange processes. Other techniques may be able to investigate the sources and dynamics of nutrients (e.g., nitrogen and phosphorus) (Garzon-Garcia et al. 2017; Tiecher et al. 2019). Furthermore, sediment source fingerprinting may help investigate sediment connectivity (Koiter et al. 2013a; Chartin et al. 2017) and help validate watershed sediment models. Even striving to understand the behaviour of sediment source fingerprints and whether or not they are conservative (Pawlowski and Karwan 2019) and how pedogenetic and/or geologic processes drive source signal (i.e., fingerprint) development (Batista et al. 2019) will provide more information on a variety of different processes occurring in the critical zone. Indeed, more research is required to investigate the multitude of processes that 
establish the fingerprint source signals and drive their behavior during sediment generation, transportation, and deposition processes. Understanding fingerprint signal development and its behavior during these processes will go a long way to improving the reliability and robustness of sediment source fingerprinting research in addition to furthering our understanding of critical zone processes.

\section{Conclusions}

There has been a considerable advancement in the sediment source fingerprinting technique over the last several decades. In particular, the research focus has somewhat shifted away from understanding geomorphic processes towards highlighting the main sources (e.g., land use) contributing deleterious sediment loads in order to help guide management interventions. Along with a management focus, there has been a considerable drive in the literature to advance modeling techniques and reduce model uncertainty.

As the sediment source fingerprinting technique has advanced considerably, we believe it is time to return to one of the early foci of the technique: researching erosion and sediment delivery processes. As Uber et al. (2019) demonstrated, the model applied was not as important as the different fingerprints used in the model. As such, we believe it is time for sediment source fingerprinting research to move away from model-centric research programs to focus more on understanding the key processes driving the source contributions to sediment. Indeed, this may create a unique and yet a difficult balance for researchers to strive for. A balance that contributes to advancing some of the modeling nuances, sampling techniques, tracer selection approaches, and source apportionment strategies, while also including a direct objective to advance our understanding of dynamic processes in the critical zone.

Accordingly, we believe it would be beneficial for researchers to continue combining multiple sets of fingerprints (e.g., geochemistry and fallout radionuclides) together to help move sediment fingerprinting research forward. In particular, it will be important for researchers to use multiple sets of fingerprints in research projects and publications to capitalize on the power of simultaneously examining temporal, spatial, and process dynamics responsible for the relative source contributions of sediment transiting river networks. Furthermore, research with multiple sets of fingerprints may also help researchers investigate the cumulative effects of anthropogenic or natural disturbances with next-generation fingerprints. The more we research and understand the unique processes that establish the source fingerprint signals and influence the conservative behavior of fingerprints, the more we may begin to understand the key processes driving the mobilization, generation, and deposition of sediment, particulate matter, and even their bound contaminants, in the critical zone.
Acknowledgments We would like to extend our sincere gratitude to Moira Ledger and Phil Owens who helped make this special issue possible. We would also like to thank the authors that contributed to this special issue along with the multiple reviewers who provided timely and constructive feedback on the submitted manuscripts. Indeed, the effort and time provided by reviewers have significantly helped advance the sediment source fingerprinting technique. Finally, we would like to kindly thank Pedro Batista and Hugh Smith for their comments and feedback on this preface along with John Clune and John Hammond for internal U.S. Geological Survey reviews.

\section{References}

Amundson R, Richter DD, Humphreys GS, Jobbágy EG, Gaillardet J (2007) Coupling between biota and earth materials in the critical zone. Elements 3(5):327-332

Banwart S, Bernasconi SM, Bloem J, Blum W, Brandao M, Brantley S, Chabaux F, Duffy C, Kram P, Lair G (2011) Soil processes and functions in critical zone observatories: hypotheses and experimental design. Vadose Zone J 10(3):974-987

Bartley R, Thompson C, Croke J, Pietsch T, Baker B, Hughes K, KinseyHenderson A (2018) Insights into the history and timing of postEuropean land use disturbance on sedimentation rates in catchments draining to the great barrier reef. Mar Pollut Bull 131:530-546

Batista P, Laceby JP, Silva M, Tassinari D, Bispo D, Curi N, Davies J, Quinton JN (2019) Using pedological knowledge to improve sediment source apportionment in tropical environments. J Soils Sediments. https://doi.org/10.1007/s11368-018-2199-5(this issue)

Belmont P, Willenbring J, Schottler S, Marquard J, Kumarasamy K, Hemmis J (2014) Toward generalizable sediment fingerprinting with tracers that are conservative and nonconservative over sediment routing timescales. J Soils Sediments 14(8):1479-1492

Ben Slimane A, Raclot D, Evrard O, Sanaa M, Lefevre I, Le Bissonnais Y (2016) Relative contribution of rill/interrill and gully/channel erosion to small reservoir siltation in Mediterranean environments. Land Degrad Dev 27(3):785-797

Bilotta GS, Brazier RE (2008) Understanding the influence of suspended solids on water quality and aquatic biota. Water Res 42(12):2849 2861

Blake WH, Ficken KJ, Taylor P, Russell MA, Walling DE (2012) Tracing crop-specific sediment sources in agricultural catchments. Geomorphology 139-140:322-329

Boudreault M, Koiter AJ, Lobb DA, Liu K, Benoy G, Owens PN, Li S (2019) Comparison of sampling designs for sediment source fingerprinting in an agricultural watershed in Atlantic Canada. J Soils Sediments. https://doi.org/10.1007/s11368-019-02306-6(this issue)

Brantley SL, Goldhaber MB, Ragnarsdottir KV (2007) Crossing disciplines and scales to understand the critical zone. Elements 3(5):307314

Caitcheon GG (1993) Sediment source tracing using environmental magnetism - a new approach with examples from Australia. Hydrol Process 7(4):349-358

Carter J, Owens PN, Walling DE, Leeks GJL (2003) Fingerprinting suspended sediment sources in a large urban river. Sci Total Environ 314-316:513-534

Chartin C, Evrard O, Laceby JP, Onda Y, Ottlé C, Lefèvre I, Cerdan O (2017) The impact of typhoons on sediment connectivity: lessons learnt from contaminated coastal catchments of the Fukushima Prefecture (Japan). Earth Surf Process Landf 42:306-317

Clark EH (1985) The off-site costs of soil erosion. J Soil Water Conserv 40(1):19-22

Collins AL, Walling DE (2002) Selecting fingerprint properties for discriminating potential suspended sediment sources in river basins. $\mathrm{J}$ Hydrol 261(1-4):218-244 
Collins AL, Walling DE, Leeks GJL (1996) Composite fingerprinting of the spatial source of fluvial suspended sediment: a case study of the Exe and Severn river basins, United Kingdom. Géomorphologie 2(2):41-53

Collins AL, Zhang Y, McChesney D, Walling DE, Haley SM, Smith P (2012) Sediment source tracing in a lowland agricultural catchment in southern England using a modified procedure combining statistical analysis and numerical modelling. Sci Total Environ 414:301317

Collins AL, Foster IDL, Gellis AC, Porto P, Horowitz AJ (2017) Sediment source fingerprinting for informing catchment management: methodological approaches, problems and uncertainty. J Environ Manag 194:1-3

Collins AL, Burak E, Harris P, Pulley S, Cardenas L, Tang Q (2019) Field scale temporal and spatial variability of $\delta 13 \mathrm{C}, \delta 15 \mathrm{~N}, \mathrm{TC}$ and TN soil properties: implications for sediment source tracing. Geoderma 333:108-122

Cooper RJ, Krueger T (2017) An extended Bayesian sediment fingerprinting mixing model for the full Bayes treatment of geochemical uncertainties. Hydrol Process 31(10):1900-1912

Cooper RJ, Krueger T, Hiscock KM, Rawlins BG (2015) High-temporal resolution fluvial sediment source fingerprinting with uncertainty: a Bayesian approach. Earth Surf Process Landf 40(1):78-92

Crutzen PJ (2002) Geology of mankind. Nature 415(6867):23-23

D'Haen K, Verstraeten G, Degryse P (2012) Fingerprinting historical fluvial sediment fluxes. Prog Phys Geogr 36(2):154-186

Davies J, Olley J, Hawker D, McBroom J (2018) Application of the Bayesian approach to sediment fingerprinting and source attribution. Hydrol Process 32(26):3978-3995

Davis CM, Fox JF (2009) Sediment fingerprinting: review of the method and future improvements for allocating nonpoint source pollution. J Environ Eng 135(7):490-504

Douglas G, Caitcheon G, Palmer M (2009) Sediment source identification and residence times in the Maroochy River estuary, Southeast Queensland, Australia. Environ Geol 57(3):629-639

Douglas G, Kuhnen M, Radke LC, Hancock G, Brooke B, Palmer MJ, Pietsch T, Ford PW, Trefry MG, Packett R (2010) Delineation of sediment sources to a coastal wetland in the great barrier reef catchment: influence of climate variability and land clearing since European arrival. Environ Chem 7(2):190-206

Evrard O, Navratil O, Ayrault S, Ahmadi M, Némery J, Legout C, Lefèvre I, Poirel A, Bonté P, Esteves M (2011) Combining suspended sediment monitoring and fingerprinting to determine the spatial origin of fine sediment in a mountainous river catchment. Earth Surf Process Landf 36(8):1072-1089

Evrard O, Laceby JP, Huon S, Lefèvre I, Sengtaheuanghoung O, Ribolzi O (2016) Combining multiple fallout radionuclides (137Cs, 7Be, $210 \mathrm{Pbxs}$ ) to investigate temporal sediment source dynamics in tropical, ephemeral riverine systems. J Soils Sediments 16(3):1130 1144

Evrard O, Durand R, Foucher A, Tiecher T, Sellier V, Onda Y, Lefèvre I, Cerdan O, Laceby JP (2019a) Using spectrocolourimetry to trace sediment source dynamics in coastal catchments draining the main Fukushima radioactive pollution plume (2011-2017). J Soils Sediments. https://doi.org/10.1007/s11368-019-02302-w(this issue)

Evrard O, Laceby JP, Ficetola GF, Gielly L, Huon S, lefèvre I, Onda Y, Poulenard J (2019b) Environmental DNA provides information on sediment sources: a study in catchments affected by Fukushima radioactive fallout. Sci Total Environ 665:873-881

Foster IDL, Boardman J, Keay-Bright J (2007) Sediment tracing and environmental history for two small catchments, Karoo uplands, South Africa. Geomorphology 90(1-2):126-143

Fox JF (2009) Identification of sediment sources in forested watersheds with surface coal mining disturbance using carbon and nitrogen isotopes. J Am Water Resour Assoc 45(5):1273-1289
Gaillardet J (2014) Editorial preface: the Earth's critical zone. Proced Earth Plan Sci 10:1-2

Gartner J, Renshaw C, Dade W, Magilligan F (2012) Time and depth scales of fine sediment delivery into gravel stream beds: constraints from fallout radionuclides on fine sediment residence time and delivery. Geomorphology 151:39-49

Garzon-Garcia A, Laceby JP, Olley JM, Bunn SE (2017) Differentiating the sources of fine sediment, organic matter and nitrogen in a subtropical Australian catchment. Sci Total Environ 575:1384-1394

Gateuille D, Owens PN, Petticrew EL, Booth BP, French TD, Déry SJ (2019) Determining contemporary and historical sediment sources in a large drainage basin impacted by cumulative effects: the regulated Nechako River, British Columbia, Canada. J Soils Sediments. https://doi.org/10.1007/s11368-019-02299-2(this issue)

Gellis AC, Gorman Sanisaca L (2018) Sediment fingerprinting to delineate sources of sediment in the agricultural and forested Smith Creek watershed, Virginia, USA. J Am Water Resour Assoc 54(6):1197-1221

Gellis AC, Mukundan R (2013) Watershed sediment source identification: tools, approaches, and case studies. J Soils Sediments 13(10): $1655-1657$

Gellis AC, Walling DE (2011) Sediment source fingerprinting (tracing) and sediment budgets as tools in targeting river and watershed restoration programs, stream restoration in dynamic fluvial systems: scientific approaches, analyses, and tools. Geophys. Monogr. Ser. AGU, Washington, DC, pp 263-291

Gellis AC, Fuller CC, Van Metre P, Filstrup CT, Tomer MD, Cole KJ, Sabitov TY (2019) Combining sediment fingerprinting with agedating sediment using fallout radionuclides for an agricultural stream, Walnut Creek, Iowa, USA. J Soils Sediments. https:// doi.org/10.1007/s11368-018-2168-z(this issue)

Griggs D, Stafford-Smith M, Gaffney O, Rockström J, Öhman MC, Shyamsundar P, Steffen W, Glaser G, Kanie N, Noble I (2013) Policy: sustainable development goals for people and planet. Nature 495(7441):305-307

Guo L, Lin H (2016) Critical zone research and observatories: current status and future perspectives. Vadose Zone J 15(9):1-14

Guzmán G, Quinton J, Nearing M, Mabit L, Gómez J (2013) Sediment tracers in water erosion studies: current approaches and challenges. J Soils Sediments 13(4):816-833

Haddadchi A, Ryder DS, Evrard O, Olley J (2013) Sediment fingerprinting in fluvial systems: review of tracers, sediment sources and mixing models. Int J Sediment Res 28(4):560-578

Hancock GJ, Revill AT (2013) Erosion source discrimination in a rural Australian catchment using compound-specific isotope analysis (CSIA). Hydrol Process 27(6):923-932

Hooke RL, Martín-Duque JF, Pedraza J (2012) Land transformation by humans: a review. GSA Today 22(12):4-10

Jalowska AM, McKee BA, Laceby JP, Rodriguez AB (2017) Sources and fate of suspended sediment in the lower Roanoke River, North Carolina. Catena 154:95-106

Kitch JL, Phillips JM, Peukert S, Taylor A, Blake W (2019) Understanding the geomorphic consequences of enhanced overland flow in mixed agricultural systems: sediment fingerprinting demonstrates the need for integrated upstream and downstream thinking. J Soils Sediments. https://doi.org/10.1007/s11368-019-02378-4(this issue)

Koiter A, Lobb D, Owens P, Petticrew E, Tiessen KD, Li S (2013a) Investigating the role of connectivity and scale in assessing the sources of sediment in an agricultural watershed in the Canadian prairies using sediment source fingerprinting. J Soils Sediments 13(10):1676-1691

Koiter AJ, Owens PN, Petticrew EL, Lobb DA (2013b) The behavioural characteristics of sediment properties and their implications for sediment fingerprinting as an approach for identifying sediment sources in river basins. Earth-Sci Rev 125:24-42

Kraushaar S, Schumann T, Ollesch G, Schubert M, Vogel H-J, Siebert C (2015) Sediment fingerprinting in northern Jordan: element specific 
correction factors in a carbonatic setting. J Soils Sediments 15(10): 2166-2173

Laceby JP, Olley J (2015) An examination of geochemical modelling approaches to tracing sediment sources incorporating distribution mixing and elemental correlations. Hydrol Process 29:1669-1685

Laceby JP, Huon S, Onda Y, Evrard O (2016) Do forests represent a longterm source of contaminated particulate matter in the Fukushima Prefecture? J Environ Manag 183:742-753

Laceby JP, Evrard O, Smith H, Blake W, Olley J, Minella JPG, Owens PN (2017) The challenges and opportunities of addressing particle size effects in sediment source fingerprinting: a review. Earth-Sci Rev 169:85-103

Ladha JK, Singh Y, Erenstein O, Hardy B (eds) (2009) Integrated crop and resource management in the rice-wheat system of South Asia. International Rice Research Institute (IRRI) Philippines, 395 pp

Le Gall M, Evrard O, Thila F, Foucher A, Laceby JP, Salvador-Blanes S, Ayrault S (2017) Examining suspended sediment sources and dynamics during flood events in a drained catchment using stable strontium isotopes. Chem Geol 449:147-157

Lin H (2010) Earth's critical zone and hydropedology: concepts, characteristics, and advances. Hydrol Earth Syst Sci 14(1): $25-45$

Longmore M, O'Leary B, Rose C, Chandica A (1983) Mapping soil erosion and accumulation with the fallout isotope caesium- 137 . Aust J Soil Res 21(4):373-385

Mahoney DT, Al Aamery N, Fox JF, Riddle B, Ford W, Wang Y (2019) Equilibrium sediment exchange in the earth's critical zone: evidence from sediment fingerprinting with stable isotopes and watershed modeling. J Soils Sediments. https://doi.org/10.1007/s11368-0182208-8(this issue)

Martínez-Carreras N, Udelhoven T, Krein A, Gallart F, Iffly JF, Ziebel J, Hoffmann L, Pfister L, Walling DE (2010) The use of sediment colour measured by diffuse reflectance spectrometry to determine sediment sources: application to the Attert River catchment (Luxembourg). J Hydrol 382(1-4):49-63

Matisoff G (2014) 210Pb as a tracer of soil erosion, sediment source area identification and particle transport in the terrestrial environment. J Environ Radioact 138:343-354

Mukundan R, Walling DE, Gellis AC, Slattery MC, Radcliffe DE (2012) Sediment source fingerprinting: transforming from a research tool to a management tool. J Am Water Resour Assoc 48(6):1241-1257

Murray AS, Olive LJ, Olley JM, Caitcheon GG, Wasson RJ, Wallbrink PJ (1993) Tracing the source of suspended sediment in the Murrumbidgee River, Australia. In: Peters NE, Hoehn E, Leibundgut C, Tase N, Walling DE (eds) Tracers in hydrology, IAHS publication no. 215. IAHS Press, Wallingford, pp 293-302

Nosrati K, Collins AL (2019) Investigating the importance of recreational roads as a sediment source in a mountainous catchment using a fingerprinting procedure with different multivariate statistical techniques and a Bayesian un-mixing model. J Hydrol 569:506-518

Nosrati K, Collins AL, Madankan M (2018) Fingerprinting sub-basin spatial sediment sources using different multivariate statistical techniques and the modified MixSIR model. Catena 164:32-43

NRC (2001) Basic Research Opportunities in Earth Science. National Research Council (NRC), National Academy Press, Washington, DC

NSF-CZO (2019) Earth's critical zone extends from above the tree canopy to bedrock. National Science Foundation, Critical Zone Observatory (NSF-CZO), from: https://www.nsf.gov/news/mmg/ mmg_disp.jsp?med_id=184231\&from (retrieved May 31, 2019)

Oldfield F, Rummery TA, Thompson R, Walling DE (1979) Identification of suspended sediment sources by means of magnetic measurements: some preliminary results. Water Resour Res 15(2):211-218

Olley J, Caitcheon G (2000) Major element chemistry of sediments from the Darling-Barwon river and its tributaries: implications for sediment and phosphorus sources. Hydrol Process 14(7):1159-1175
Olley J, Brooks A, Spencer J, Pietsch T, Borombovits D (2013) Subsoil erosion dominates the supply of fine sediment to rivers draining into Princess Charlotte bay, Australia. J Environ Radioact 124:121-129

Owens P, Batalla R, Collins A, Gomez B, Hicks D, Horowitz A, Kondolf G, Marden M, Page M, Peacock D (2005) Fine-grained sediment in river systems: environmental significance and management issues. River Res Appl 21(7):693-717

Owens PN, Blake WH, Gaspar L, Gateuille D, Koiter AJ, Lobb DA, Petticrew EL, Reiffarth D, Smith HG, Woodward JC (2016) Fingerprinting and tracing the sources of soils and sediments: earth and ocean science, geoarchaeological, forensic, and human health applications. Earth-Sci Rev 162:1-23

Palazón L, Latorre B, Gaspar L, Blake WH, Smith HG, Navas A (2015) Comparing catchment sediment fingerprinting procedures using an auto-evaluation approach with virtual sample mixtures. Sci Total Environ 532:456-466

Pawlowski ED, Karwan DL (2019) Assessment of lead and beryllium sorption to exposed stream channel sediment under varying freshwater channel conditions. J Soils Sediments. https://doi.org/10. 1007/s11368-019-02245-2(this issue)

Porto P, Walling DE, Callegari G (2010) Using 137Cs measurements to establish catchment sediment budgets and explore scale effects. Hydrol Process 25(6):886-900

Pulley S, Foster I, Antunes P (2015) The application of sediment fingerprinting to floodplain and lake sediment cores: assumptions and uncertainties evaluated through case studies in the Nene Basin, UK. J Soils Sediments 15(10):2132-2154

Reiffarth DG, Petticrew EL, Owens PN, Lobb DA (2016) Sources of variability in fatty acid (FA) biomarkers in the application of compound-specific stable isotopes (CSSIs) to soil and sediment fingerprinting and tracing: a review. Sci Total Environ 565:8-27

Reiffarth DG, Petticrew EL, Owens PN, Lobb DA (2019) Spatial differentiation of cultivated soils using compound-specific stable isotopes (CSSIs) in a temperate agricultural watershed in Manitoba, Canada. J Soils Sediments. https://doi.org/10. 1007/s11368-019-02406-3(this issue)

Richter D, Mobley ML (2009) Monitoring Earth's critical zone. Science 326(5956):1067-1068

Ruddiman WF, Ellis EC, Kaplan JO, Fuller DQ (2015) Defining the epoch we live in. Science 348(6230):38-39

Sherriff SC, Franks SW, Rowan JS, Fenton O, Ó'hUallacháin D (2015) Uncertainty-based assessment of tracer selection, tracer nonconservativeness and multiple solutions in sediment fingerprinting using synthetic and field data. J Soils Sediments 10:2101-2116

Small IF, Rowan JS, Franks SW (2002) Quantitative sediment fingerprinting using a Bayesian uncertainty estimation framework. IAHS AISH Publ 276:443-450

Smith BD, Zeder MA (2013) The onset of the Anthropocene. Anthropocene 4:8-13

Smith HG, Blake WH, Owens PN (2013) Discriminating fine sediment sources and the application of sediment tracers in burned catchments: a review. Hydrol Process 27(6):943-958

Smith HG, Blake WH, Taylor A (2014) Modelling particle residence times in agricultural river basins using a sediment budget model and fallout radionuclide tracers. Earth Surf Process Landf 39(14): 1944-1959

Smith H, Evrard O, Blake W, Owens P (2015) Preface — addressing challenges to advance sediment fingerprinting research. J Soils Sediments 15(10):2033-2037

Smith HG, Peñuela A, Sangster H, Sellami H, Boyle J, Chiverrell R, Schillereff D, Riley M (2018) Simulating a century of soil erosion for agricultural catchment management. Earth Surf Process Landf 43:2089-2105

Steffen W, Broadgate W, Deutsch L, Gaffney O, Ludwig C (2015) The trajectory of the Anthropocene: the great acceleration. Anthropocene Rev 2(1):81-98 
Stewart HA, Massoudieh A, Gellis A (2015) Sediment source apportionment in Laurel Hill creek, PA, using Bayesian chemical mass balance and isotope fingerprinting. Hydrol Process 29(11):2545-2560

Stott AP (1986) Sediment tracing in a reservoir-catchment system using a magnetic mixing model. Phys Earth Planet Inter 42(1-2):105-112

Taylor A, Blake WH, Smith HG, Mabit L, Keith-Roach MJ (2013) Assumptions and challenges in the use of fallout beryllium-7 as a soil and sediment tracer in river basins. Earth-Sci Rev 126:85-95

Tiecher T, Minella JPG, Caner L, Evrard O, Zafar M, Capoane V, Le Gall M, Santos DR (2017) Quantifying land use contributions to suspended sediment in a large cultivated catchment of southern Brazil (Guaporé River, Rio Grande do Sul). Agric Ecosyst Environ 237:95-108

Tiecher T, Ramon R, Laceby JP, Evrard O, Minella JPG (2019) Potential of phosphorus fractions to trace sediment sources in a rural catchment of southern Brazil: comparison with the conventional approach based on elemental geochemistry. Geoderma 337:1067-1076

Uber M, Legout C, Nord G, Crouzet C, Demory F, Poulenard J (2019) Comparing alternative tracing measurements and mixing models to fingerprint suspended sediment sources in a mesoscale Mediterranean catchment. J Soils Sediments. https://doi.org/10. 1007/s11368-019-02270-1(this issue)

Wallbrink PJ (2004) Quantifying the erosion processes and land-uses which dominate fine sediment supply to Moreton Bay, Southeast Queensland, Australia. J Environ Radioact 76(1-2):67-80

Wallbrink PJ, Murray AS (1993) Use of fallout radionuclides as indicators of erosion processes. Hydrol Process 7(3):297-304

Wallbrink PJ, Murray AS, Olley JM, Olive LJ (1998) Determining sources and transit times of suspended sediment in the Murrumbidgee River, New South Wales, Australia, using fallout 137Cs and 210Pb. Water Resour Res 34(4):879-887
Walling DE (2005) Tracing suspended sediment sources in catchments and river systems. Sci Total Environ 344(1-3):159-184

Walling DE, Kane P (1984) Suspended sediment properties and their geomorphological significance. In: Burt TP, Walling DE (eds) Catchment experiments in fluvial geomorphology. Geo Books, Norwich, pp 311-334

Walling DE, Woodward JC, Nicholas AP (1993) A multi-parameter approach to fingerprinting suspended-sediment sources. In: Peters NE, Hoehn E, Leibundgut C, Tase N, Walling DE (eds) Tracers in hydrology. IAHS publication no. 215. IAHS Press, Wallingford, pp 329-338

Walling DE, Golosov V, Olley J (2013) Introduction to the special issue 'tracer applications in sediment research'. Hydrol Process 27(6): 775-780

Waters CN, Zalasiewicz J, Summerhayes C, Barnosky AD, Poirier C, Gałuszka A, Cearreta A, Edgeworth M, Ellis EC, Ellis M (2016) The Anthropocene is functionally and stratigraphically distinct from the Holocene. Science 351(6269):137-147

Wittmann H, von Blanckenburg F, Guyot JL, Laraque A, Bernal C, Kubik PW (2011) Sediment production and transport from in situ-produced cosmogenic $10 \mathrm{Be}$ and river loads in the Napo River basin, an upper Amazon tributary of Ecuador and Peru. J S Am Earth Sci 31(1):45-53

Wood PA (1978) Fine-sediment mineralogy of source rocks and suspended sediment, rother catchment, West Sussex. Earth Surf Process Landf 3(3):255-263

Publisher's note Springer Nature remains neutral with regard to jurisdictional claims in published maps and institutional affiliations. 